\title{
A New Viral Coinfection: SARS-CoV-2 Pneumonia and Cytomegalovirus Pneumonitis in a Renal Transplant Recipient
}

\author{
Abdullah S. Shaikh ${ }^{1, *}$, Hila Shaim ${ }^{1}$, Maria A. Caravedo ${ }^{2}$, Karen M. Ong ${ }^{1}$ and David Reynoso ${ }^{2}$ (I) \\ 1 Department of Internal Medicine, Division of General Medicine, University of Texas Medical Branch, \\ Galveston, TX 77555, USA; hishaim@utmb.edu (H.S.); kmong@utmb.edu (K.M.O.) \\ 2 Department of Internal Medicine, Division of Infectious Disease, University of Texas Medical Branch, \\ Galveston, TX 77555, USA; macarave@utmb.edu (M.A.C.); dareynos@utmb.edu (D.R.) \\ * Correspondence: asshaikh@utmb.edu
}

check for

updates

Citation: Shaikh, A.S.; Shaim, H.; Caravedo, M.A.; Ong, K.M.; Reynoso, D. A New Viral Coinfection: SARS-CoV-2 Pneumonia and Cytomegalovirus Pneumonitis in a Renal Transplant Recipient. COVID 2021, 1, 115-119. https://doi.org/ 10.3390/covid1010010

Academic Editor: Roger Frutos

Received: 1 June 2021

Accepted: 4 July 2021

Published: 7 July 2021

Publisher's Note: MDPI stays neutral with regard to jurisdictional claims in published maps and institutional affiliations.

Copyright: (c) 2021 by the authors. Licensee MDPI, Basel, Switzerland. This article is an open access article distributed under the terms and conditions of the Creative Commons Attribution (CC BY) license (https:// creativecommons.org/licenses/by/ $4.0 /)$.

\begin{abstract}
SARS-CoV-2 has caused a global pandemic of an acute respiratory illness known as COVID19. Patients with solid organ transplants receiving chronic immunosuppressive therapy are at risk of severe disease caused by opportunistic pathogens, including cytomegalovirus (CMV). We present the case of a renal transplant recipient presenting with hypoxic respiratory failure because of severe COVID-19, whose course was complicated by ganciclovir-resistant CMV pneumonitis.
\end{abstract}

Keywords: transplant; kidney; cytomegalovirus; CMV; COVID-19; SARS-CoV-2

\section{Introduction}

The novel coronavirus SARS-CoV-2 has caused a global pandemic of an acute respiratory illness known as COVID-19, with over 25 million cases and over 800,000 deaths as of August 2020 [1]. The risk factors for severe illness among all age groups include hypertension, malignancy, chronic kidney disease (CKD), chronic obstructive pulmonary disease (COPD), an immunocompromised state secondary to solid organ transplant, congestive heart failure (CHF), diabetes mellitus (DM), among other conditions [2]. Additionally, patients with solid organ transplants receiving chronic immunosuppressive therapy are at risk of severe disease caused by opportunistic pathogens, including cytomegalovirus (CMV). A CMV infection is one of the most common infectious complications of solid organ transplant recipients and has variable clinical features, ranging from asymptomatic infection to severe tissue-invasive disease involving the lung, intestines, liver, pancreas and other organs. Tissue-invasive disease is associated with increased morbidity and mortality [3]. We present the case of a renal transplant recipient presenting with hypoxic respiratory failure because of severe COVID-19, whose course was complicated by ganciclovir-resistant CMV pneumonitis.

\section{Case Description}

A 36-year-old male presented to an outside hospital with fever and acute hypoxic respiratory failure secondary to COVID-19, requiring oxygen supplementation via a highflow nasal cannula.

He was the recipient of a cadaveric renal transplant secondary to diffuse membranous glomerulonephritis ten months prior to this admission (CMV serostatus: donor positive/recipient negative). His maintenance immunosuppressive regimen included cyclosporine and mycophenolate, and he was receiving a prophylactic dose of valganciclovir (450 mg twice daily). His prophylactic dose had been increased three months prior from $450 \mathrm{mg}$ once daily to twice daily because of high CMV viral load (63,000 copies/mL) with good response (decrease to 2800 copies / $\mathrm{mL}$ a month later).

Upon admission to the outside hospital, he was recognized to have severe COVID-19, and received remdesivir, convalescent plasma and dexamethasone. He also received 
empiric ceftriaxone (seven days) and azithromycin (three days) for community acquired pneumonia. After two weeks of treatment, he lacked significant clinical improvement, and continued to have persistent fevers, pulmonary infiltrates and high oxygen requirements. He was then started on empiric Pneumocystis jiroveci (PJP) treatment with clindamycin and primaquine (trimethoprim/sulfamethoxazole was precluded by kidney injury), and his antimicrobial coverage was broadened to meropenem, vancomycin and fluconazole. These empiric therapies also yielded no clinical improvement.

The patient was transferred to our hospital with persistent hypoxic respiratory failure after three weeks of hospitalization at the outside facility. On admission, his CMV viral load was noted to have increased from 2800 copies to 36,000 copies in one month while on prophylactic valganciclovir. Given these concerning findings for CMV pneumonitis and ganciclovir resistance, his mycophenolate and cyclosporine were both stopped and he was started on prednisone $5 \mathrm{mg}$ daily. Given high-flow oxygen requirements of $>55 \mathrm{~L} / \mathrm{min}$, the pulmonary team believed it would not be safe to perform a diagnostic bronchoscopy for biopsy. On day ten of admission, labs showed an increase in acute phase reactants as well as an increase in the CMV viral load to 94,000 copies, concerning for disease progression (Table A1 in Appendix A). Given the high suspicion of CMV pneumonitis, he was started on high-dose ganciclovir $10 \mathrm{mg} / \mathrm{kg} /$ day on day 12 of admission with an immediate resolution of fever after $48 \mathrm{~h}$. His oxygen requirements slowly decreased, and the patient was able to be weaned off oxygen on day 10 of ganciclovir treatment. He was then started on tacrolimus in addition to prednisone for immunosuppression and the tacrolimus dose was gradually increased.

The ganciclovir resistance panel revealed a UL97-c603w mutation. However, foscarnet was not added and the patient continued treatment with high-dose ganciclovir because of his significant clinical improvement. He was discharged 3 weeks after ganciclovir initiation, at which time the CMV viral load was 793 copies (Table A2). At discharge, he was ambulatory, did not require supplemental oxygen, and was switched to letermovir $480 \mathrm{mg}$ daily for CMV prophylaxis.

\section{Discussion}

Asymptomatic CMV infection can be seen in patients with serum viral loads between 2000-5000 copies, while active CMV disease/severe tissue invasive disease can be seen in patients with viral loads of approximately 70,000 copies [4,5], as in our patient. The gold standard for the diagnosis of invasive forms of disease is a tissue biopsy of the affected organ(s) showing inclusion bodies [4], though diagnosis can be supported by elevated viral load on bronchoalveolar lavage (BAL) samples [6]. Unfortunately, we were unable to obtain a tissue sample though BAL for definitive diagnosis because of the patient's high oxygen requirements, which increased his risk for complications with a bronchoscopy. Nonetheless, a clinical diagnosis of CMV pneumonitis is supported by his decreasing CMV viremia in parallel with his clinical improvement after high-dose ganciclovir and an otherwise negative infectious workup (Table A3).

Our patient had several risk factors for developing active pulmonary CMV disease. $\mathrm{He}$ is a CMV seronegative recipient of a seropositive donor and had a resistant strain of CMV that predisposed him to CMV disease despite valganciclovir prophylaxis [7]. CMV-seronegative recipients (CMV IgG negative prior to transplant) who receive an organ from seropositive donors are at especially high risk of CMV disease, as they acquire a primary CMV infection with transplant and receive immunosuppressants of cell-mediated immune response [8]. In addition, the prophylactic dose of valganciclovir had not been appropriate for the majority of his post-transplant course (450 mg daily instead of $900 \mathrm{mg}$ daily). While there are studies that suggest $450 \mathrm{mg}$ of valganciclovir daily is sufficient CMV prophylaxis in kidney transplant patients [9], including those at intermediate risk [10], given the patient's high risk of CMV infection, valganciclovir $900 \mathrm{mg}$ daily was the more appropriate prophylactic dose [11,12]. Finally, our patient was treated with over two weeks of dexamethasone for severe COVID-19 at the outside hospital, which further suppressed 
his immune system and predisposed him to develop an opportunistic infection such as CMV disease.

Ganciclovir resistance in CMV develops in patients who receive prolonged drug exposure with only a partial suppression of CMV [13]. Incomplete adherence to the prophylactic regimen and sub-therapeutic dosing can similarly contribute to adaptive selection of resistant CMV strains. Moreover, some studies have shown that approximately $90 \%$ of ganciclovir-resistant CMV infections occur in seronegative recipients of a seropositive donors [14]. Our patient received a lower prophylactic dose of valganciclovir (450 mg daily) than he likely needed for over 7 months, and he was also a CMV seronegative recipient of a seropositive donor, both significant risk factors for developing ganciclovir-resistant CMV.

Given the high suspicion of a ganciclovir-resistant CMV strain, treatment was initiated with high-dose ganciclovir, as the most common mutation can be overcome with increased doses of ganciclovir [8]. The patient showed significant improvement after this treatment, with defervescence $48 \mathrm{~h}$ after the initiation of high-dose ganciclovir, and a gradual resolution of hypoxic respiratory failure. His resistance panel confirmed a UL97-c603w mutation, a mutation that has not yet been completely characterized [15], but, as per guidelines, should be treated with foscarnet [16]. However, given the risk of renal toxicity and his significant clinical improvement on high-dose ganciclovir, foscarnet was avoided, and the patient eventually was discharged home without supplemental oxygen.

Clinically, this case should be regarded as a viral co-infection. We do not know whether SARS-CoV2 precipitated the expansion of CMV, or vice versa. Interestingly, the patient appeared to present with severe COVID-19, but given his high CMV viral load, he may have had mild COVID-19 with CMV pneumonitis truly driving his respiratory failure. His immunosuppressive regimen included cyclosporine and mycophenolate, which inhibit lymphocyte proliferation, differentiation, activation, cytokine production and the migration of inflammatory cells. It can thus diminish cytokine storm, preventing severe COVID-19 [17,18]. On the other hand, it may also hamper the anti-viral immune response, enabling unopposed viral replication [19]. However, in the setting of his rapid clinical improvement on a CMV antiviral therapy, CMV is most likely the major contributor to the patient's clinical presentation and his prolonged respiratory failure.

Reports on the clinical course and treatment of renal transplant patients with COVID19 are still sparse, with only a handful of case reports available [18,20]. To our knowledge, this is one of the first reports of CMV pneumonitis in the setting of COVID-19. In another case report by Damiano D'Ardes et al. [21], the diagnosis of CMV pneumonitis was suggested by elevated IgG and IgM, but treatment for CMV was not initiated. However, given our patient's significant clinical improvement after treatment with high-dose ganciclovir and the marked decrease in his CMV viral load, we are confident in our clinical diagnosis of CMV pneumonitis. We recommend that clinicians treating COVID-19 maintain a high index of suspicion for co-infection in immunocompromised patients with atypical or prolonged respiratory failure.

Author Contributions: Conceptualization, A.S.S., M.A.C. and D.R.; methodology, A.S.S. and D.R.; formal analysis, A.S.S., M.A.C. and D.R.; investigation, A.S.S., M.A.C. and D.R.; writing-original draft preparation, A.S.S., H.S. and K.M.O.; writing-review and editing, M.A.C. and D.R.; supervision, D.R.; project administration, D.R. All authors have read and agreed to the published version of the manuscript.

Funding: This research received no external funding.

Institutional Review Board Statement: Ethical review and approval were waived for this study because the information in the case report is not a systematic investigation.

Informed Consent Statement: Written informed consent has been obtained from the patient to publish this paper.

Data Availability Statement: Not applicable.

Conflicts of Interest: The authors declare no conflict of interest. 


\section{Appendix A}

Table A1. General and Inflammatory Laboratory Values.

\begin{tabular}{|c|c|c|c|c|c|c|c|}
\hline Variable & $\begin{array}{l}\text { Reference } \\
\text { Range }\end{array}$ & $\underset{\text { Admission }}{\text { OSH }}$ & Day $1 \ddagger$ & Day 4 & Day 8 & Day $12 \S$ & Day 23 \\
\hline COVID-19 & Negative & $\begin{array}{l}\text { Positive } \\
\text { (PCR) }\end{array}$ & $\begin{array}{c}\text { Positive } \\
\text { (Rapid ID NOW) }\end{array}$ & - & - & - & - \\
\hline Lactic Acid & $0-2.2 \mathrm{mMol} / \mathrm{L}$ & 0.70 & 0.85 & - & - & - & - \\
\hline $\begin{array}{l}\text { C Reactive } \\
\text { Protein }\end{array}$ & $<0.8 \mathrm{mg} / \mathrm{dL}$ & - & $18.0(\mathrm{H})$ & - & - & $19.2(\mathrm{H})$ & - \\
\hline Procalcitonin & $<0.07 \mathrm{ng} / \mathrm{mL}$ & $0.25(\mathrm{H})$ & $0.4(\mathrm{H})$ & - & - & - & - \\
\hline D-Dimer & $<0.5 \mu \mathrm{g} / \mathrm{mL}$ & - & $0.83(\mathrm{H})$ & - & $9.46(\mathrm{H})$ & - & $1.29(\mathrm{H})$ \\
\hline Creatinine & $0.6-1.25 \mathrm{~g} / \mathrm{dL}$ & - & $1.32(\mathrm{H})$ & $2.59(\mathrm{H})$ & $2.35(\mathrm{H})$ & 0.99 & 0.85 \\
\hline Albumin & $3.5-5.0 \mathrm{~g} / \mathrm{dL}$ & - & $2.4(\mathrm{~L})$ & $2.6(\mathrm{~L})$ & - & - & - \\
\hline $\begin{array}{c}\text { Lactate } \\
\text { Dehydrogenase }\end{array}$ & 300-600 U/L & - & $1050(\mathrm{H})$ & $1327(\mathrm{H})$ & - & - & - \\
\hline $\begin{array}{l}\text { White Blood } \\
\text { Cell Count }\end{array}$ & $\begin{array}{c}4.2-10.7 \times \\
10^{3} / \mu \mathrm{L}\end{array}$ & - & 6.07 & 5.12 & - & $0.99(\mathrm{~L})$ & 5.6 \\
\hline $\begin{array}{c}\text { Absolute } \\
\text { Neutrophil Count }\end{array}$ & $\begin{array}{c}1.99-6.95 \times \\
10^{3} / \mu \mathrm{L}\end{array}$ & - & 5.71 & 4.92 & - & $0.57(\mathrm{~L})$ & 4.78 \\
\hline $\begin{array}{c}\text { Absolute } \\
\text { Lymphocyte Count }\end{array}$ & $\begin{array}{c}1.09-3.23 \times \\
10^{3} / \mu \mathrm{L}\end{array}$ & - & $0.22(\mathrm{~L})$ & $0.11(\mathrm{~L})$ & - & $0.11(\mathrm{~L})$ & $0.54(\mathrm{~L})$ \\
\hline $\begin{array}{c}\text { Oxygen } \\
\text { Requirement }\end{array}$ & - & $\begin{array}{l}\text { High-Flow } \\
(30 \mathrm{~L} / \mathrm{min}, \\
\left.100 \% \mathrm{FiO}_{2}\right)\end{array}$ & $\begin{array}{c}\text { Non-Rebreather } \\
\text { Mask } \\
\text { (15 L/min) }\end{array}$ & $\begin{array}{l}\text { High-Flow } \\
(50 \mathrm{~L} / \mathrm{min}, \\
\left.100 \% \mathrm{FiO}_{2}\right)\end{array}$ & $\begin{array}{l}\text { High-Flow } \\
(55 \mathrm{~L} / \mathrm{min}, \\
\left.60 \% \mathrm{FiO}_{2}\right)\end{array}$ & $\begin{array}{l}\text { High-Flow } \\
(55 \mathrm{~L} / \mathrm{min}, \\
\left.70 \% \mathrm{FiO}_{2}\right)\end{array}$ & $\begin{array}{c}\text { Nasal } \\
\text { Cannula } \\
(4 \mathrm{~L})\end{array}$ \\
\hline
\end{tabular}

${ }^{\dagger}$ Admission to outside hospital (OSH), 3 weeks prior to admission to UTMB; ${ }^{\ddagger}$ Admission to UTMB; $§ 1$ st dose of high-dose ganciclovir.

Table A2. Cytomegalovirus (CMV) Trend.

\begin{tabular}{cccccccccc}
\hline Lab & Reference Range & $\begin{array}{c}\text { Renal } \\
\text { Transplant }\end{array}$ & CV 1 & CV 2 & Day 2 & Day 10 & Day 18 & Day 24 & Day 32 ${ }^{\mathbb{I}}$ \\
\hline CMV IgG & Negative & Negative & - & - & - & - & - & - & - \\
\hline CMV PCR & $<2.5 \log \mathrm{IU} / \mathrm{mL}$ & - & 4.6 & 3.2 & 4.3 & 4.7 & 3.9 & 2.9 & 2.7 \\
\hline CMV PCR $(\log )$ & $<300 \mathrm{IU} / \mathrm{mL}$ & - & 36,814 & 1644 & 21,130 & 55,098 & 7293 & 735 & 461 \\
\hline CMV PCR & $<2.7 \log$ copies $/ \mathrm{mL}$ & - & 4.8 & 3.5 & 4.6 & 5.0 & 4.1 & 3.1 & 2.9 \\
\hline CMV PCR $(\log )$ & $<516$ copies $/ \mathrm{mL}$ & - & 63,320 & 2828 & 36,344 & 94,769 & 12,544 & 1264 & 793 \\
\hline
\end{tabular}

${ }^{\dagger}$ Renal transplant occurred 10 months prior to admission to UTMB; ${ }^{\ddagger}$ Clinic visit 1 and 2 ; clinic visit 1 was 2 months prior to admission to

UTMB and clinic visit 2 was 1 month prior to admission to UTMB; ${ }^{\S}$ Day 2 of admission to UTMB; ${ }^{\text {II }}$ Day of discharge from UTMB.

Table A3. Infectious Workup.

\begin{tabular}{ccc}
\hline Lab & OSH $^{+}$ & UTMB \\
\hline Urinalysis & Negative & Negative \\
\hline Coccidiodes Ab IgM & Negative & Negative \\
\hline Coccidiodes Ab IgG & Negative & Negative \\
\hline Cryptococcal Antigen & Negative & Negative \\
\hline Histoplasma Antigen & - & Negative \\
\hline Histoplasma Antigen (Urine) & Negative & Negative \\
\hline Fungitell & Negative & Negative \\
\hline Blood Culture & - & No Growth \\
\hline Urine Culture & - & No Growth \\
\hline Fungal Culture & - & No Growth \\
\hline AFB Culture & - & No Growth \\
\hline Respiratory Viral Panel & - & Negative \\
\hline Pneumococcal Antigen (Urine) & - & Negative \\
\hline Legionella Antigen (Urine) & - & Negative \\
\hline Aspergillus Galactomannan Antigen & - & Negative \\
\hline
\end{tabular}




\section{References}

1. World Health Organization. Coronavirus Disease (COVID-19) Weekly Epidemiological Update. Available online: https://www. who.int/docs/default-source/coronaviruse/situation-reports/20200831-weekly-epi-update-3.pdf?sfvrsn=d7032a2a_4 (accessed on 26 August 2020).

2. $\quad$ Li, X.; Xu, S.; Yu, M.; Wang, K.; Tao, Y.; Zhou, Y.; Shi, J.; Zhou, M.; Wu, B.; Yang, Z.; et al. Risk factors for severity and mortality in adult COVID-19 inpatients in Wuhan. J. Allergy Clin. Immunol. 2020, 146, 110-118. [CrossRef]

3. Karuthu, S.; Blumberg, E.A. Common infections in kidney transplant recipients. Clin. J. Am. Soc. Nephrol. 2012, 7, 2058-2070. [CrossRef]

4. Humar, A.; Gregson, D.; Caliendo, A.M.; McGeer, A.; Malkan, G.; Krajden, M.; Corey, P.; Greig, P.; Walmsley, S.; Levy, G.; et al Clinical utility of quantitative cytomegalovirus viral load determination for predicting cytomegalovirus disease in liver transplant recipients. Transplantation 1999, 68, 1305-1311. [CrossRef]

5. Cariani, E.; Pollara, C.P.; Valloncini, B.; Perandin, F.; Bonfanti, C.; Manca, N. Relationship between pp65 antigenemia levels and real-time quantitative DNA PCR for Human Cytomegalovirus (HCMV) management in immunocompromised patients. BMC Infect. Dis. 2007, 7, 138. [CrossRef] [PubMed]

6. Humar, A.; Michaels, M.; AST ID Working Group on Infectious Disease Monitoring. American Society of Transplantation recommendations for screening, monitoring and reporting of infectious complications in immunosuppression trials in recipients of organ transplantation. Am. J. Transplant. 2006, 6, 262-274. [CrossRef] [PubMed]

7. Hartmann, A.; Sagedal, S.; Hjelmesaeth, J. The natural course of cytomegalovirus infection and disease in renal transplant recipients. Transplantation 2006, 82 (Suppl. 2), S15-S17. [CrossRef] [PubMed]

8. Lurain, N.S.; Chou, S. Antiviral drug resistance of human cytomegalovirus. Clin. Microbiol. Rev. 2010, 23, 689-712. [CrossRef] [PubMed]

9. Avery, R.K. Low-dose valganciclovir for cytomegalovirus prophylaxis in organ transplantation: Is less really more? Clin. Infect. Dis. 2011, 52, 322-324. [CrossRef] [PubMed]

10. Halim, M.A.; Al-Otaibi, T.; Gheith, O.; Adel, H.; Mosaad, A.; Hasaneen, A.-A.; Zakaria, Z.; Makkeya, Y.; Said, T.; Nair, P. Efficacy and Safety of Low-Dose Versus Standard-Dose Valganciclovir for Prevention of Cytomegalovirus Disease in Intermediate-Risk Kidney Transplant Recipients. Exp. Clin. Transplant. 2016, 14, 526-534. [CrossRef] [PubMed]

11. Stevens, D.R.; Sawinski, D.; Blumberg, E.; Galanakis, N.; Bloom, R.D.; Trofe-Clark, J. Increased risk of breakthrough infection among cytomegalovirus donor-positive/recipient-negative kidney transplant recipients receiving lower-dose valganciclovir prophylaxis. Transpl. Infect. Dis. 2015, 17, 163-173. [CrossRef] [PubMed]

12. Dupuis, R.; Harris, M.; Gillis, K.; Gerber, D.; Fair, J.; Watson, R.; Koslowski, T.; Andreoni, K. Experience with low-dose valganciclovir prophylaxis in adult liver transplant recipients. Transplant. Proc. 2007, 39, 3266-3270. [CrossRef] [PubMed]

13. Boeckh, M.; Geballe, A.P. Cytomegalovirus: Pathogen, paradigm, and puzzle. J. Clin. Investig. 2011, 121, 1673-1680. [CrossRef] [PubMed]

14. Hantz, S.; Garnier-Geoffroy, F.; Mazeron, M.-C.; Garrigue, I.; Merville, P.; Mengelle, C.; Rostaing, L.; Marcoux, F.S.; Essig, M.; Rerolle, J.-P.; et al. Drug-resistant cytomegalovirus in transplant recipients: A French cohort study. J. Antimicrob. Chemother. 2010, 65, 2628-2640. [CrossRef] [PubMed]

15. Chou, S.; Ercolani, R.J.; Vanarsdall, A.L. Differentiated Levels of Ganciclovir Resistance Conferred by Mutations at Codons 591 to 603 of the Cytomegalovirus UL97 Kinase Gene. J. Clin. Microbiol. 2017, 55, 2098-2104. [CrossRef] [PubMed]

16. Razonable, R.R.; Humar, A. Cytomegalovirus in solid organ transplant recipients-Guidelines of the American Society of Transplantation Infectious Diseases Community of Practice. Clin. Transplant. 2019, 33, e13512. [CrossRef] [PubMed]

17. Molyvdas, A.; Matalon, S. Cyclosporine: An old weapon in the fight against Coronaviruses. Eur. Respir. J. 2020, 2002484. [CrossRef] [PubMed]

18. Chen, D.; Yang, B.; Zhang, Y.; Chen, L.; Wei, L.; Zhang, W.; Wang, X.; Tong, L.; Chen, Z. Withdrawing mycophenolate mofetil in treating a young kidney transplant recipient with COVID-19: A case report. Medicine 2020, 99, e20481. [CrossRef] [PubMed]

19. Bataille, S.; Moal, V.; Gaudart, J.; Indreies, M.; Purgus, R.; Dussol, B.; Zandotti, C.; Berland, Y.; Vacher-Coponat, H. Cytomegalovirus risk factors in renal transplantation with modern immunosuppression. Transpl. Infect. Dis. 2010, 12, 480-488. [CrossRef] [PubMed]

20. Arpali, E.; Akyollu, B.; Yelken, B.; Tekin, S.; Turkmen, A.; Kocak, B. Case report: A kidney transplant patient with mild COVID-19. Transpl. Infect. Dis. 2020, 22, e13296. [CrossRef] [PubMed]

21. D'Ardes, D.; Boccatonda, A.; Schiavone, C.; Santilli, F.; Guagnano, M.T.; Bucci, M.; Cipollone, F. A Case of Coinfection with SARS-COV-2 and Cytomegalovirus in the Era of COVID-19. Eur. J. Case Rep. Intern. Med. 2020, 7, 001652. [CrossRef] [PubMed] 